\title{
5 \\ To Condemn a Bishop in Flight
}

But they [Athanasius's accusers] were so overwhelmed by the consciousness of their own evil deeds that they took to flight and, by this flight, clearly proved the falsity of their accusation, as well as their own guilt.

-THEODORET, ECCLESIASTICAL HISTORY ${ }^{1}$

Not all Christian flights were created equal. With the aid of pro-Nicene authors, Athanasius of Alexandria's multiple flights quickly became the standard for an orthodox exile. But the charge of cowardice-or worse, heresy-was not so easily dismissed. While Athanasius attempted to explain away such charges, as did many of his defenders, not all could escape such a damning verdict. In this and the following chapter, we will explore how the enemies of Nicaea, reread as the enemies of Athanasius, also found themselves in exile. But their episcopal flights were no testament to their virtue. As the quote from Theodoret's Ecclesiastical History above demonstrates, the exiles of anti-Nicene bishops were remembered within pro-Nicene Christian tradition as evidence of their guilt.

The post-Nicene age may have begun with Athanasius's death, but the legends of Nicaea began with the literary birth of his enemy, the Arians. ${ }^{2}$ This birth was intimately tied to his life in flight, as I demonstrated in chapters 1 and 2. And we explored in chapter 4 how Athanasius's Encyclical Letter inaugurated his exilic discourse as both the victim of-and victor over-heresy. As should be evident by now, it is impossible to have heroes without villains. The pro-Nicene contingent created larger-than-life enemies to reinforce their status as victims, whether they be emperors or heretics. Despite the best efforts of later pro-Nicene authors,

1. Theodoret, Eccl. Hist. 2.6. Greek: L. Parmentier, F. Scheidweiler, and G. C. Hansen, Theodoretus Cyri, Kirchengeschichte, 3rd ed., GCS, vol. 19 (Berlin 1998). Translations of text are in consult with the Greek and NPNF2 3, unless otherwise noted.

2. For the beginning of the post-Nicene age, see Richard Lim, Public Disputation, Power, and Social Order in Late Antiquity (Berkeley: University of California Press, 1995), 183. For the beginning of the legends of Nicaea with the creation of the Arians, see Burrus, Begotten, Not Made, 48-58. 
those villainous anti-Nicene bishops were not always representative of a minority point of view. In fact, from 325 to 337 , it appeared as if Nicaea's ideals would be overthrown. A series of councils in the Eastern Roman Empire appeared to have replaced its more controversial claims, such as the now (in)famous term homoousios. Many cities within Asia Minor were decidedly anti-Nicene and had begun to rally around particular figures to combat what they perceived to be heretical ideas espoused by Alexander of Alexandria and his successor, Athanasius. Two cities, in particular, stand out both in the heat of the moment and well after the conflict over Nicaea had come and gone, namely, Nicomedia and Antioch. ${ }^{3}$ In these final two chapters, we will turn to these two powerful urban centers to once again assess how episcopal flight from particular spaces was intimately tied to the process of crafting orthodoxy.

Here we will critically examine the various competing narratives related to the exile and legacy of Athanasius's chief enemy, Eusebius of Nicomedia. Even though Eusebius died the bishop of Constantinople, his memory was tied to an alternate, and theologically rich, space. We will begin by assessing how the city of Nicomedia became a significant focus within the memory-making exercise of the fourth- and fifth-century ecclesiastical historians. Next, we will turn to Nicomedia's role in how its bishop, Eusebius, would be remembered. We then will attempt to reconcile why the bishop of Nicomedia's episcopal career might pose a spatial threat to proNicene historians. Finally, we will conclude that Eusebius's flight from and return to the city of Nicomedia was woven into a recognizable and effective story of failure. And so, now, we once again turn to the city in order to better understand the man who fled from it.

\section{HOW TO CONDEMN A MODEL CITY: NICOMEDIA}

The city of Nicomedia, founded in 264 BCE, was given its name by Nicomedes I. It was the capital of Bithynia Prima, while its neighbor, the city of Nicaea, was frequently referred to as the capital of Bithynia Secunda. ${ }^{4}$ The fourth-century writer Lactantius, among others, note that Nicomedia was the favored imperial residence of that nefarious emperor Diocletian, who made it the eastern Roman capital in 286 CE. ${ }^{5}$ It was also in Nicomedia that the young Constantine was tutored and where he prepared for his position as the future Caesar-a position

3. Ayres reconstructs the series of councils, key bishops, and cities that made a significant effort to undermine the creeds established at Nicaea; see Ayres, Nicaea and Its Legacy, 101-3.

4. For a recent entry on Nicomedia and Nicaea, see Klaus Belke, Bithynien und Hellespont (TIB 13), in press / forthcoming, s.v. Nikomedeia / Nikaia. Belke breaks down the archeological evidence as well as literary references to these significant cities.

5. For a biographical reconstruction of Lactantius's time in Nicomedia and when and where he wrote his Divine Institutes and On the Death of Persecutors, see T. D. Barnes, Constantine and Eusebius (Cambridge, MA: Harvard University Press, 1981), $291 n 96$. 
he was ultimately denied, in favor of Galerius. The most damning detail, however, remains that Nicomedia was where the edict of the Great Persecution in 303 was issued and where Lactantius reportedly witnessed firsthand attacks on the Christian community. ${ }^{6}$ It was in Nicomedia that Eusebius of Caesarea, another foundational ecclesiastical historian, states that the co-emperor Licinius would ultimately lose his life for his continued use of violence against Nicomedian Christians even after Constantine's edict of toleration was put into effect. It is unsurprising that later pro-Nicene historians place a great deal of emphasis on this fact. Nicomedia's reigning significance as a site of Christian persecution and the seedbed of the most horrific enemies of the church was not lost on later pro-Nicene writers.

And still, Nicomedia's significance as a powerful city in Christian memory continued to pose a set of historical challenges for those invested in condemning its memory. As our two earliest historians argue, Nicomedia remained an ambivalent space for Christians. Both Lactantius and Eusebius of Caesarea spent a great deal of their career either in or writing about Nicomedia, and they provide us with a rare glimpse into the historical exercise of remembering a contested city. Again, it is from Lactantius that we hear firsthand how Diocletian's persecution was sparked within the city's walls. And it is his detailed reports concerning the burning of books, the destruction of churches, and the first executions that are later recycled in many of the texts we have already explored.7 It is also from Eusebius of Caesarea that we learn about the persistence of persecutions even after Constantine's successful military campaign. Despite these details, not all visions of Nicomedia were negative.

These fourth-century authors also understood how space could be imbued with cultural and religious significance under the right circumstances. Jeremy Schott has argued, following the lead of Bruno Breckman and T. D. Barnes, that Nicomedia was the site where Constantine delivered his Speech to the Assembly of

6. "While it was still twilight the prefect came to the church with military leaders, tribunes, and accountants. They forced open the doors and searched for the image of God. They found the scriptures and burnt them; all were granted booty; the scene was one of plunder, panic, and confusion.... Bringing axes and other iron tools, and after being ordered from every direction, they leveled the lofty edifice to the ground within a few hours" (Lactantius, Mort. 12.2-5). Edition: SC 39 and Creed, Lactantius, De Mortibus Persecutorum. Translation: David M. Gwynn, Christianity in the Later Roman Empire: A Sourcebook (London: Bloomsbury, 2015), 20 (with some slight alterations).

7. When we place this narrative alongside the details in Athanasius's Encyclical Letter, we are presented with a counter-narrative. The burning of church buildings as evidence of Christian persecution stands out. And, as Shepardson has argued in her examination of the contested readings of the ruins of the burned Temple of Apollo, the destruction of the built landscape played an important role in identifying orthodox spaces during this period; see Shepardson, Controlling Contested Places, 67-79. As we have already seen, Athanasius takes great pains to note that the persecution in Alexandria began with attacks on two important churches in the city. A similar case was made earlier by Lactantius, who remarked that the destruction of the Nicomedian church was seen as a direct assault on Christianity. See chapter 4. 
Saints. ${ }^{8}$ In this speech, preserved in in Eusebius's Life of Constantine, we learn that Constantine describes Licinius as its unworthy champion and then condemns its heritage of persecution. ${ }^{9}$

The great city acknowledges this and praises with acclamation; and also the people of the dearest city wish <to do the same $>$, even if formerly, deceived by false hopes, it chose a champion unworthy of itself, who was at once caught in a manner appropriate to and worthy of his rash deeds, which it is not right to record, especially for me, as I speak to you and take all care to address you with holy and auspicious utterances. ${ }^{10}$

In the storyline of that great savior, the emperor Constantine, only one champion can redeem the city's sordid past. Licinius, unable to occupy the savior's position, seized hold of this territory and could not resist the temptation to persecute its Christian inhabitants. Constantine, by way of contrast, was the only true victor, the one who could break this curse.

At the end of Eusebius of Caesarea's panegyric, we learn that even this great man could not resist the allure of the city. ${ }^{11}$ While the emperor chose to build a new city in the port city of Byzantium, he nevertheless decided to reside and then die in Nicomedia, not Constantinople. Eusebius goes on to report that Constantine's crowning moment was his decision to be baptized on his deathbed and to encourage others to follow his lead. ${ }^{12}$

And yet this last imperial act was not enough to wash away the stain of persecution that persisted in Nicomedia and threatened to mar the emperor's reputation. Constantine's baptism took place in Nicomedia remained an embarrassing detail that later writers sought to explain away. Even Eusebius of Caesarea made frequent attempts to say that the company the emperor kept at the end of his life was not

8. Jeremy Schott also takes note of this memory-making process; see Schott, Christianity, Empire, and the Making of Religion in Late Antiquity (Philadelphia: University of Pennsylvania Press, 2008), 111-13. Schott highlights the significance of Nicomedia as the presumed site of Porphyry's anti-Christian polemics during and after the Christian persecution or where Lactantius wrote his Divine Institutes as an eyewitness to the destruction of the Christian churches $(53,81-82)$.

9. Constantine, Speech, 25.4. This speech is preserved in Eusebius of Caesarea, Vit. Const. Efforts to preserve the text as separate from Eusebius's panegyric have resulted in the critical edition by I. A. Heikel, Eusebius Werke, 7 vols., Die Griechischen Christlichen Schriftsteller 7 (Leipzig: Hinrichs, 1902), 1:151-92. Translation: Barnes, Constantine and Eusebius, 30.

10. Constantine, Speech, 22.1.

11. For a description of the end of Constantine's life and his baptism, see Eusebius of Caesarea, Life of Constantine 4.61-64. Editions: CPG 3495; SC 31, 41, 55. Translation: Averil Cameron and Stuart George Hall, Eusebius: Life of Constantine, Clarendon Ancient History Series (Oxford: Clarendon, 1999).

12. As Gwynn notes, Constantine's baptism by Eusebius of Nicomedia is only overtly credited by Jerome in Chronicon 2353. The pro-Nicene authors go to great lengths to avoid directly associating the baptism with the Nicomedian bishop. See Gwynn, Eusebians, 18n44. See also Garth Fowden's discussion of the various traditions associated with Constantine's baptism in "The Last Days of Constantine: Oppositional Versions and Their Influence," Journal of Roman Studies 84 (1994): 153-70. 
without the occasional false Christian-alluding to the number of false Christians in Nicomedia. Nicomedia and its questionable legacy must be overcome. Yet Nicomedia-and, we will soon see, its bishop-must be dealt with precisely because Constantine was baptized and died there. The memory of both Constantine and that doomed city was eventually transformed, and like Athanasius's, Constantine (along with his memory) was safely transferred to Constantinople, not only to preserve the orthodoxy of the emperor but also to ensure the damning of his more problematic companion, Eusebius of Nicomedia.

\section{AN UNORTHODOX RETURN FROM FLIGHT: EUSEBIUS OF NICOMEDIA}

Eusebius of Nicomedia, the so-called leader of the Eusebians after the council of Nicaea, lived on in infamy primarily for his ongoing support of Arius and his staunch opposition to Athanasius. ${ }^{13}$ In the aftermath of the Nicene council, Alexander of Alexandria condemned Eusebius and his efforts to rehabilitate Arius. After Alexander's death, Athanasius followed closely in his mentor's stead and targeted Eusebius and his followers for his own polemical purposes. The evolution of animosity between the Alexandrian patriarchate and Eusebius is well documented. And it is unsurprising why this would be so. Eusebius appears to have been behind the appointments of both Gregory and George of Cappadocia and, according to Athanasius, was the mastermind behind many of the travesties committed in Alexandria. ${ }^{14}$

Although little is known about Eusebius's life other than his dealings with proNicene politics, many have assumed some familial ties to the imperial household. According to the ecclesiastical historian Philostorgius, whom we will explore in more detail below, Eusebius was a student under Lucian of Antioch, also known as Lucian the Martyr, and quickly rose through the ranks of both political and ecclesiastical importance..$^{15}$ Eusebius was, without a doubt, a well-connected man and a powerful broker of imperial politics. For instance, his familial connections were frequently commented upon by ecclesiastical historians. He appears to have had some relation with Julius Julianus, the praetorian prefect for the emperor Licinius (315-324) in the East-that is, the emperor who quickly lost his life when

13. For a helpful overview of Eusebius's contemporary biographical reconstruction, see Gwynn, Eusebians, 1133 .

14. See chapter 1.

15. Philostorgius, Eccl. Hist. 2.12. Edition: Joseph Bidez, Philostorgius, Kirchengeschichte. Mit dem Leben des Lucian von Antiochien und den Fragmenten eines arianischen Historiographen, ed. Joseph Bidez, rev. Friedhelm Winkelmann, GCS (Berlin: Akademie Verlag, 1981). Translation: Philip R. Amidon, Philostorgius: Church History (Atlanta, GA: Society of Biblical Literature, 2007), unless otherwise noted. It was Helena, Constantine's mother, who discovered the remains of the martyr Lucian washed up on the shores of Nicomedia. This detail is also preserved in Eusebius of Caesarea, Vit. Const. 52. The territory around the bay of Nicomedia is said to have been renamed Helenopolis after Constantine's mother. 
Constantine had had enough of shared rule. Surprisingly, even after Licinius's defeat, Eusebius appears to have retained his political influence and became an important member of the inner circle of Constantine. This appears to have been due to Licinius's wife, Constantia, who was Constantine's half-sister. The imperial interfamily politics, however brutal the outcome for many, continued to work in Eusebius's favor throughout his life and career.

A few other connections, more dubious in nature, are frequently commented on. Most notable was the rumor that Eusebius briefly tutored Julian-later emperor and Christian apostate. His association or influence over the young Julian might be another attempt to malign the bishop's reputation. ${ }^{16}$ Nevertheless, the relationship Eusebius had with imperial circles was an intimate one, though it was tense at times. Eusebius, like Athanasius, was exiled under Constantine. And while this exile is frequently noted by ecclesiastical historians such as Socrates (Eccl. Hist. 2.1) and Sozomen (Eccl. Hist. 2.28), many of the details are left out.

The reasons behind Eusebius's short exile and his return, like those of Athanasius's many flights, are difficult to reconstruct. ${ }^{17}$ It is unclear whether it was Constantine who initiated Eusebius's removal in September-October 325 (Socrates, Eccl. Hist. 1.9; Sozomen, Eccl. Hist. 1.21) or a particularly active pro-Nicene council of bishops (Philostorgius, Eccl. Hist. 1.10, 2.1). Eusebius, like Athanasius, appears to have been exiled to Gaul along with the lesser known Theognis (Socrates, Eccl. Hist. 2.8). And like the Alexandrian bishop, he is permitted to return. His return is equally as difficult to reconstruct. Socrates insists he is permitted to return in 328 after Constantia, Constantine's half-sister, is said to have appealed to the emperor on his behalf (Socrates, Eccl. Hist. 1.14). As we have explored elsewhere, a similar appeal was made on Athanasius's behalf by Constans, the youngest son of Constantine..$^{18}$ And so the historian is left to ask if Eusebius eventually restored to his episcopal see due to the reconnaissance efforts initiated by his friends at court? Or was he allowed to return because his version of orthodoxy was slowly becoming the favored interpretation among eastern bishops? These questions cannot be answered here. What we are able to glean from this particular departure and return is how Eusebius's exile plays into his legacy as a heretic, even when all evidence points to

16. See Ammianus Marcellinus, Res Gest. 22.9.4. Aetius, of the so-called heteroousian faction, was also presumed to be a tutor of Julian. The emperor addresses a personal letter to Aetius, recalling him from exile and inviting him to visit him, due to their old acquaintance.

17. Some scholars insist that Eusebius advocated on behalf of Licinius and that this was one of the reasons why Constantine exiled the bishop. Theodoret preserves Constantine's Letter to the Church of Nicomedia (Theodoret, Eccl. Hist. 1.20). In the letter, Eusebius is presented as a co-conspirator in Licinius's tyrannical activities. I am not convinced this was actually written by Constantine but am inclined to see it as a later interpolation to support Theodoret's reconstruction of the past. For a biographical reconstruction of this position, see Gwynn, Eusebians, 117n38. The text is preserved in part in Theodoret, Eccl. Hist. 1.20; and Gelasius of Cyzicus, Eccl. Hist. 1.1-17.

18. For the conflict between Athanasius and Constantius, see chapter 1. 
a successful, even orthodox, career. His beginnings, like many of the enemies of Nicaea we have encountered before, are evident at the very start of his career.

Prior to his flight from Nicomedia, Eusebius is often described as a wanderer. After a brief time as bishop of Berytus, he was appointed to the much larger and significant see of Nicomedia. If this move was not enough to call attention to his questionable character, according to Theodoret, the infamous heretic Arius wrote to Eusebius soon after he was condemned by Alexander in $318 .{ }^{19}$ Eusebius appears to have championed Arius's cause, and he felt the strict disapproval of Alexander soon after. Socrates also preserved Alexander's intense disdain of this meddlesome bishop's tactics: "Eusebius, now bishop in Nicomedia, thinks that the affairs of the church lay under his control. ... He has now established himself at the head of these apostates, daring even to write in all directions in support of them, hoping to drag down some of the ignorant into this shameful and anti-Christian heresy" (Eccl. Hist. 1.6.4). ${ }^{20}$

Eusebius's reception of Arius (and his compatriots) is an obvious reason why later pro-Nicene historians condemned Eusebius. The company one keeps is surely enough reason to dismiss a bishop in flight, as we saw with John Chrysostom. ${ }^{21}$ While this explanation is one of the main reasons why this bishop was so easily maligned, we might look for other reasons why Eusebius's memory would be damned.

Unfortunately, like Eusebius's life, little is known about his actual theological leanings; few of his writings remain, and those that do are suspect, given that they were preserved by his opponents. For instance, his Letter to Arius was found in Athanasius's On the Synod, and Theodoret was responsible for preserving his Letter to Paulinus of Tyre. ${ }^{22}$ It is also telling that a questionable text titled Letter of Recantation makes it into Socrates's Ecclesiastical History along with a handful of sayings that made it into Sozomen's account. ${ }^{23}$ What we are able to discern is that this bishop, like Athanasius, found himself the victim of exile in the aftermath of Nicaea. And he, too, returns to his episcopal post as a triumphant victor. And when he did return, Eusebius's life and career swiftly took off. He was entrusted with the coveted Constantinopolitan bishopric in 338, and then he died a natural death a few years later, in 342. By all accounts, Eusebius had a resoundingly successful career.

19. Theodoret preserves a letter presumably written by Arius to Eusebius in 319 (Eccl. Hist. 1.3, 4). He argues that the letter serves as proof of Alexander's report of Arius's tactics and circle of heretical supporters.

20. The letter is preserved as Letter of Alexander of Alexandria to all Bishops. Translation: NFPF2 $2.3-5$.

21. See chapter 4 .

22. Letter to Arius (CPG 2046); Letter to Paulinus of Tyre (CPG 2045). His other writings that survive are Letter to the Council of Nicaea (fragment, CPG 2047) and Letter of Recantation of Eusebius and Theognis of Nicaea (CPG 2048).

23. Letter to the Council of Nicaea (CPG 2047) and Letter of Recantation of Eusebius and Theognis of Nicaea (CPG 2048). 
What continues to stand out when assessing the history of this particular bishop in flight is the insistence of linking Eusebius to Nicomedia. Not only was Eusebius the one who baptized the emperor on his deathbed, but Eusebius was also appointed the bishop of Constantinople. Why, then, is Eusebius remembered as a heretic rather than as an orthodox bishop? If we move beyond an overtly doctrinal and theological reconstruction (although these details do and will play a role) and look instead at the spatial arguments, we might begin to see how this process plays out in the minds of later writers. Before we turn to those reports, we will examine how an anti-Nicene historian insisted we remember Eusebius. Philostorgius of Cappadocia reveals the stakes involved in remembering Eusebius as either a failed or successful bishop. In his version of events, Philostorgius revives Nicomedia and reminds his readers that this city remained the space of imperial and ecclesiastical power well into the fourth century. ${ }^{24} \mathrm{His}$ presentation of Nicomedia as an important city and Eusebius as a hero points to the various rhetorical strategies deployed by other ecclesiastical historians to downplay the success of both.

\section{HOW TO REHABILITATE A BISHOP: PHILOSTORGIUS OF CAPPADOCIA'S ECCLESIASTICAL HISTORY}

Of all the ecclesiastical historians in the aftermath of Nicaea, Philostorgius of Cappadocia provides us with a rare glimpse into an alternate vision of Christian history. ${ }^{25}$ While his voice ought to be critically evaluated alongside the voices of his contemporaries, he does present a different view of interparty politics and an alternative character evaluation of the major players involved in the controversy. For example, Constantine does not come across as the infallible hero in Philostorgius's account. Instead, we hear of an unpredictable character willing to put to death his firstborn son, Crispus, and second wife, Fausta, as well as exhibit an intense sense of paranoia. ${ }^{26}$

24. All of our authors made note of the earthquake that devastated the city. Nicomedia was eventually rebuilt and appeared to remain an important strategic location for waging military campaigns, but in the minds of pro-Nicene Christian historians, it never regained its former glory. A recent archaeological research team under the support of the Scientific and Technological Research Council of Turkey (TÜBİTAK) and lead by Tuan Sare Agturk has resulted in some fascinating discoveries at the ancient site of Nicomedia and modern-day Izmit. These include sculpted colorful relief panels that reveal a lively and flourishing metropolis in the fourth century. Belke also notes that Nicomedia was the location of one of Asia Minor's three mints and remained a valuable port city for trade throughout late antiquity.

25. For notes on the problems related to the manuscript, see Amidon, Philostorgius, xxiii-xxv.

26. Philostorgius says that Crispus (or Pricus) was killed due to an illicit relationship (or false accusation of one) with Constantine's second wife, Fausta, who is eventually caught in adultery with another man (presumably not Crispus), is killed by being suffocated to death in a sealed bath. See Philostorgius, Eccl. Hist. 2.4. 
As an ardent defender of an anti-Nicene contingent, Philostorgius has been frequently dismissed. Thomas Ferguson has recently made significant headway in advancing our understanding of this historian. ${ }^{27}$ Philostorgius appears to have composed his Ecclesiastical History in Constantinople between 425 and 433, and he catalogues events between 320 and 425. And in his retelling of the immediate aftermath of Nicaea, Eusebius's exile lasts for three years (Eccl. Hist. 2.7). When Eusebius was eventually recalled by Constantine, we see a reversal in the Nicene tide: Alexander was cast out of Alexandria, and Eustathius was expelled from Antioch. ${ }^{28}$ To emphasize the significance of this change, Philostorgius proclaims Eusebius was soon after awarded the bishopric of Constantinople (Eccl. Hist. 2.10). To add to this auspicious event, the remains of the martyr Lucian were discovered by the emperor's mother, Helena, at the bay of Nicomedia (Eccl. Hist. 2.12). Philostorgius is careful to stress that Lucian was the patron saint of Eusebius throughout his career and is undoubtedly the reason why the bishop was able to round out his career in Constantinople.

Another hero is repeatedly lauded in this text alongside Eusebius. Constantius II, unlike his father, was the preferred imperial protagonist in Philostorgius's account. The working relationship between Eusebius and Constantius provides the historian with a poignant narrative twist. After Constantine fell ill, in the thirty-second year of his reign, he blamed his brothers for poisoning him (Eccl. Hist. 2.16). While on his deathbed, Constantine called Eusebius to his side and entrusted him with a letter describing the plot against his life. His letter was to be given to his favored son, Constantius (and not the eldest son, Constantine II), along with his will in order to bring his killers to account.

To further extol the favored son's virtues, Philostorgius remarks that it was Constantius, in control of the eastern empire, who erected the Great Church in Constantinople and transferred the bones of Andrew, Luke, and Timothy to the sanctuary (Eccl. Hist. 3.2). Most importantly, Constantius was responsible for deposing Eusebius's archenemy, Athanasius. Even after Athanasius manipulated the youngest son of Constantine, Constans, and secured his return, Constantius was not fooled but saw right through Athanasius's duplicitous character. The emperor's decision to replace Athanasius with George of Cappadocia was a defining moment and a decisive victory (Eccl. Hist. 3.3). ${ }^{29}$ For Philostorgius, a great deal of good could come from Cappadocia. ${ }^{30}$

27. Thomas Ferguson, The Past Is Prologue: The Revolution of Nicene Historiography (Leiden: Brill, 2005). Joseph Bidez has also careful reconstructed the pieces of this history; see Philostorgius, Kirchengeschichte: mit dem Leben des Lucian von Antiochien und den Fragmenten eines arianischen Historiographen, ed. Joseph Bidez (Berlin: Akademie, 1913).

28. For a description of Eustathius's exile, see chapter 3.

29. Gregory of Cappadocia is not mentioned here, and Amidon (Philostorgius, 39n6) suggests this was a chronological mix-up.

30. Cappadocia, like Nicomedia, would be a flag for nefarious activity. See chapter 1 for a discussion of how Athanasius's episcopal replacements are frequently referred to as Cappadocians and the significance of their outsider status. 
The emperor's constant vigilance ensured that a homoiousian position was upheld. For instance, Constantius called for two councils to settle the matter: one in the West, at Rimini, and one in the East, at Nicomedia. Here we learn about a devastating earthquake in Nicomedia, which prevented the council from taking place. ${ }^{31}$ This divinely inspired event was allowed to happen, according to Philostorgius, because too many bishops present were in favor of the consubstantialist doctrine (Eccl. Hist. 4.10-11). The Eastern Roman Empire was thus saved from a decisive Nicene victory.

Let us zero in on a few details that will occupy us for the remainder of this chapter. First, Philostorgius depicts Eusebius as an orthodox bishop whose exile and return reinforced this claim to orthodoxy. He was persecuted for a brief time but returned triumphant. The brevity of his exile and the success of his career as the celebrated bishop of Constantinople served as further proof of this claim. Second, Constantine appears to have chosen Eusebius as his confidant to deliver his letter revealing the cause of his death to Constantius II. Eusebius was clearly a trustworthy man, according to Philostorgius. Finally, the cause of Nicomedia's destruction was a strong pro-Nicene contingent in the city. These points depart significantly from those preserved in the histories of our pro-Nicene authors, and they tell us a great deal about how these historians deal with the same evidence.

One story, however, is left out of this narrative: Eusebius does not baptize Constantine, even though Philostorgius does confirm that the emperor died in Nicomedia. For this anti-Nicene historian, Eusebius's success was not determined by his relationship with Constantine. That privilege is passed to the emperor's true heir and defender of orthodoxy, Constantius..$^{32}$ Philostorgius nonetheless stresses the significance of Nicomedia as the space and place where Eusebius's identity and authority was secured. Ecclesiastical historians on both sides of the Nicene debate were reluctant to let go of this spatial link. The question remains: why was the destruction of Nicomedia so important to the history Christianity? As we will soon discover, it had a great deal to with Constantinople.

\section{HOW TO CONDEMN A MODEL EXILE: SOCRATES OF CONSTANTINOPLE'S ECCLESIASTICAL HISTORY}

The life of Socrates Scholasticus remains a mystery, much like that of Eusebius. What we learn of it is pulled directly from his Ecclesiastical History. ${ }^{33}$ This major work was composed in Constantinople, where the author was born and raised

31. For discussion of the use of earthquakes in the ecclesiastical historians of the fifth century, see Edward Watts, "Interpreting Catastrophe: Disasters in the Works of Pseudo-Joshua the Stylite, Socrates Scholasticus, Philostorgius, and Timothy Aelurus," Journal of Late Antiquity 2, no. 1 (2009): 79-98.

32. Theodoret, Eccl. Hist. 1.30, mentions that Constantine was baptized on his deathbed but, like Philostorgius, does not mention that it was Eusebius who baptized him. Given Theodoret's theological leanings, we might conclude that he omitted this for different reasons than Philostorgius.

33. Greek text: P. Maraval and P. Périchon, SC, Socrate de Constantinople, Histoire ecclésiastique (books 1-7), SC 477, 493, 505, 506 (2004-2007). Trans. NPNF2. 
(Socrates, Eccl. Hist. 5.24; 5.16) and covers the period from 325 to 439 . The early chapters begin with Constantine's journey to Christianity and his defeat of its known persecutors. After the death of Licinius, Constantine was faced with a new challenge: Arianism, that more dangerous enemy, threatened to infect the entire empire. This heresy, like the persecutions only recently put down, spread like fire and would be the most significant threat to the church. Socrates writes:

And thus from a little spark a large fire was kindled, for the evil which began in the Church at Alexandria ran throughout all Egypt, Libya, and the upper Thebes, and at length diffused itself over the rest of the provinces and cities. Many others also adopted the opinion of Arius, but Eusebius, in particular, was a zealous defender of itnot he of Caesarea, but the one who had before been bishop of the church at Berytus and was then somehow in possession of the bishopric of Nicomedia in Bithynia. ${ }^{34}$

According to Socrates, the Arian heresy, although the invention of a deviant presbyter, could not have succeeded without the help of Eusebius of Nicomedia. As we pointed out above, the letter from Alexander of Alexandria is preserved in the very early stages of the composition of this ecclesiastical history, in which Alexander describes Eusebius as the lead instigator of the Arian faith. He is the "head of these apostates" (Socrates, Eccl. Hist. 1.4).

In this reconstruction of events, Nicomedia stands in direct contrast to the orthodox spaces outside its boundaries. It serves as the touch point for where the most horrific events have and will continue to take place and for where persecution is indistinguishable from heresy. Here we will focus on a few compelling spatial elements in Socrates's narrative. Whenever Constantine is found in Nicomedia, his presence there is only temporary. For example, we first hear of Constantine stopping in Nicomedia when he is first made aware of the dispute between Arius and Alexander (Eccl. Hist. 1.7). We then learn of Eusebius's exile from Nicomedia along with his supporters such as Theognis of Nicaea, Maris of Chalcedon, Theonas of Marmarica, and Secundus of Ptolemais (Eccl. Hist. 1.8).

Socrates reluctantly admits that Eusebius and the even more mysterious Theognis were in exile only for a short while, because they recanted their position. A preserved letter declares that both men supported the term homoousios, although Socrates makes it clear that this is a blatant lie, one meant to ensure their return. He then goes on to supply a number of other letters that promote more confusion than clarity. One letter is conspicuously absent in its entirety, although Socrates relays its most significant contents. The letter, addressed to the Nicomedians by the emperor, states: "Writing to the Nicomedians against Eusebius and Theognis, he [Constantine] censures the misconduct of Eusebius, not only on account of his Arianism, but also because, having formerly been well affected to the ruler, he had 
traitorously conspired against his affairs." (Eccl. Hist. 1.9). ${ }^{35}$ Here Socrates stresses that Constantine was no fool. He was fully aware of Eusebius's dubious behavior. But this absent letter is not how Socrates's version of the following events actually unfolds. Time and again, to his chagrin, the evidence appears to support rather than condemn the infamous bishop.

To distract his readers, Socrates turns to yet another letter in which Eusebius and Theognis explicitly state-and, we are therefore to conclude, falsely claimwhy they did not subscribe to Nicaea's anathemas: "We did not subscribe to the anathematizing; not as objecting to the creed, but as disbelieving the parties accused to be such as was represented, having been satisfied on this point, both from his own letters to us, and from personal conversations" (Eccl. Hist. 1.14). Here Eusebius and Theognis argue that they were guilty of trusting Arius and his party, who had fled to Nicomedia for sanctuary.

In a curious move, Socrates notes that Arius was recalled from exile before Eusebius or Theognis. Arius, however, was not permitted to return to Alexandria. Socrates stresses: "This is evident from the fact that he afterward devised a way to return for himself both into the church and into Alexandria, by having made a fictitious repentance, as we shall show in its proper place" (Eccl. Hist. 1.14, emphasis mine). As we saw in the previous chapter, to return under your own volition was unwise in the best of circumstances. Illegal return ensured one's condemnation and was an explicit act against the church. Socrates makes it clear that no matter the reasons for Arius's return - and, eventually, Eusebius's return as well-both men confirm their guilt in their illegal action. According to Socrates, once a heretic, always a heretic.

To ensure this guilty verdict, Socrates expends a great deal of energy condemning not just the bishop in flight but the city Nicomedia to further elevate Constantinople. He stresses that, from early on, Constantine's support of Christianity was intimately tied to his building campaigns:

After the synod, the emperor spent some time in recreation, and after the public celebration of his twentieth anniversary of his accession, he immediately devoted himself to the reparation of the churches. This he carried into effect in other cities as well as in the city named after him, which being previously called Byzantium, he enlarged, surrounded with massive walls, and adorned with various edifices; and having rendered it equal to imperial Rome, he named it Constantinople, establishing by law that it should be designated New Rome. This law was engraved on a pillar of stone erected in public view in the Stregium, near the emperor's equestrian statue. He built also in the same city two churches, one of which he named Irene; and the other, The Apostles. (Eccl. Hist. 1.16, emphasis mine)

35. In a side note, that is amusing, though also altogether frustrating, to contemporary historians trying to piece together Socrates's evidence; he writes: "But I thought it would be superfluous to insert here the letters respecting these things, because of their length; those who wish to do so may find them elsewhere and give them a perusal. This is sufficient notice of these transactions" (Eccl. Hist. 1.9). The modern reader will just have to take his word for it. 
In this instance, it is not just the walls of the church that make Christians, but the walls of the city, along with its edifices, statues, pillars, and two great churches. ${ }^{36}$ The reconstruction of Constantinople as a holy city was reliant upon the transference of holy relics to the center of the city. These choice items were reportedly discovered by Constantine's mother, Helena, during her pilgrimage across the empire. Socrates is careful to note that the most significant find of all was the holy cross. While a piece remained in Jerusalem, Helena sent the remainder of the true cross to Constantine, who preserved its remaining pieces in his statue in Constantinople: "The other part she sent to the emperor, who, being persuaded that the city would be perfectly secure where that relic should be preserved, privately enclosed it in his own statue, which stands on a large column of porphyry in the forum called Constantine's at Constantinople" (Eccl. Hist. 1.17). The large column houses the memory of Christ transplanted in Constantinople both to spread a proNicene Christianity and to solidify Constantine's memory as an orthodox one. His very image protects the faith.

Socrates then turns his attention back to Nicomedia. As he describes it, a war had been waged within the empire. After Eusebius of Nicomedia's return from exile, he, along with his henchman, caused even greater mischief than before. Not only are these men infected with the Arian heresy, but they make it their main objective to ensure others become infected as well. To do so, they attempt to secure Arius's return to Alexandria from Nicomedia. Eusebius first writes to Athanasius asking him to readmit Arius. Athanasius, of course, refuses the request, and Eusebius subsequently appeals directly to the emperor. His appeal is initially rejected, but we learn that Eusebius eventually worms his way into the emperor's favor by an alternate route.

As with most heretics, women are the conduits of corruption, and Eusebius decides to target Constantia, the emperor's sister. He does this by soliciting the help of an unnamed presbyter sympathetic to Eusebius's cause. ${ }^{37}$ Socrates reminds his readers that Constantia is the widow of Licinius, the last known imperial persecutor of the faith. A questionable character indeed, not unlike Eudoxia, whom we discussed in the previous chapter.

The unnamed presbyter succeeds in winning Constantia's sympathies and, upon becoming gravely ill, she appeals to her brother, who, in a touching moment, returns to Nicomedia to be by her side. On her deathbed, she appeals to her brother and asks him to trust her new advisor. She inevitably dies from one cause

36. See chapter 1 for reference to Augustine's quote, "Do walls then make Christians?" and compare with Ps.-Martyrius's claim that a city is made holy only by the men who inhabit them, discussed in chapter 4.

37. On the importance of Constantia's role in creating social networks, see Julia Hillner, "FifthCentury Church Historians: Social Network Analysts Before Their Time?” Migration of Faith (blog), April 1, 2016, www.hrionline.ac.uk/sites/clericalexile/2016/04/o1/fifth-century-church-historians-social-network-analysts-before-their-time. 
or another, and we might conclude that there was a divine hand in this imperial death as well. Constantine, in his grief and under the influence of his Nicomedian surroundings, unwisely trusts the Nicomedian presbyter. This unnamed gobetween continues to advocate on behalf of Arius, who is eventually able to return to Alexandria with a letter of imperial support in hand.

Ever the orthodox defender, Athanasius predictably refuses to admit Arius back into the church. Constantine, not one to back down from a challenge, threatens to exile Athanasius in return. Seeing their opportunity, the partisans of Eusebius continue to sway the emperor during his stay in Nicomedia. The Eusebians then conspire with the Melitians and begin to invent charges against Athanasius. Fortunately, Athanasius has a few supporters present in Nicomedia who alert the emperor to their plan. After an initial reprieve from the emperor, despite the imperial letter of support in hand, Athanasius finally has a charge of treason brought against him. Constantine then arraigns a council at Tyre to settle the matter once and for all..$^{8}$ It remains unclear whether Constantine removed himself from Nicomedia at this point, but the damage had been done. The readers-and Athanasius-find themselves soon focused upon Tyre.

Athanasius, suspicious of this turn of events, was appropriately hesitant to attend this council. When he did arrive, he remained there only long enough to point out the absurdity of the charges brought against him. In a particular humorous scene, the Melitian representatives accuse Athanasius of murder and present a severed hand as evidence. The charge was soon dismissed when Arsenius, previously believed to be dead, was found in the audience observing the spectacle. Socrates gleefully reports: "Then addressing himself to those present, he [Athanasius] said, 'Arsenius, as you see, is found to have two hands: let my accusers show the place whence the third was cut off'" (Eccl. Hist. 1.24).

Eusebius and his supporters were not so easily dissuaded and state that Athanasius may not have had a hand in killing Arsenius, but he was guilty of tampering with the grain trade. This second charge was enough to scare any man, and Athanasius fled to Constantinople. The Eusebians, hot on his trail, brought with them the same charges of treason. The result, as we have already discussed, was Athanasius's first exile, spent in Gaul. Notably, in this text, Athanasius was sent to Gaul from Constantinople. Athanasius was not the first bishop to flee to and from Gaul. As we may recall, Eusebius was also exiled to Gaul, but from Nicomedia. These spatial details are not insignificant, as we will soon see.

Socrates then turns his attention to Arius in a moment of reflection. After Arius returned to Alexandria, he stirred up trouble and was forced to flee yet again, this time to Constantinople, where another Alexander awaited him. Compelled by both the Eusebians and Constantine, Alexander was forced to readmit Arius to the church, but the very presence of the heretic divided the city. Eusebius of 
Nicomedia promised that if Arius was not readmitted, the current bishop of Constantinople would be deposed; under the threat of this promise, Alexander spent a night in prayer in the holy church of St. Irene, recently built and dedicated to Constantine. Arius and his supporters, meanwhile, paraded through the center of Constantinople to celebrate winning over the emperor and being readmitted to the church. As he passed the porphyry column, Arius was struck with an intense pain in his stomach. He quickly retreated to a privy and, in a more detailed account of his demise than even Athanasius could dream up, died an ignominious and very public death. ${ }^{39}$ This column, upon which sits the image of Constantine, was where the remains of the true cross were hidden. While Arius may have been able to fool the real emperor in Nicomedia, he was unable to fool the emperor's holy likeness in Constantinople. As Socrates points out, the statue and the cross were of the same substance. And it was under the emperor's image in the likeness of the divine that the heretic was ultimately exposed.

The battle did not end there. The stones of Constantinople were now infected with the disease of heresy, along with the stench of Arius's memory. Not even the emperor was immune. Constantine soon became ill, and Socrates reports that the emperor left Constantinople to seek out the healing baths of Helenopolis. But the soothing waters were not enough to wash away his illness, so the ailing emperor traveled to Nicomedia. Socrates is careful to note that this brief stop was not the city center of Nicomedia, but one of the surrounding suburbs. It was there that the emperor was finally baptized and died, safely away from the scent of heresy. In Socrates's account, there is no mention of Eusebius's hand in this baptism, but the proximity to the cursed city continued to linger.

Socrates's narrative clearly departs from Philostorgius's account, examined above. Socrates, for example, says that Constantine entrusted his will not to Eusebius but to an unnamed presbyter, who was charged with delivering it to Constantius II. We might recall that Philostorgius's version of Constantine's illness credits an act of poisoning by one of Constantine's brothers. Socrates, on the other hand, seems to insinuate that Constantine's illness had more to do with Arius and his demise than with any plotting relative. It was only after his final acceptance of Nicaea and baptism - not by Eusebius of Nicomedia - that Constantine died. But Constantine's memory, like the cross in Constantinople, must be preserved.

The streets of this new Rome had yet to be cleaned, and this is where book 2 of Socrates's Ecclesiastical History returns to the battle for Nicene Christianity. Alexander of Constantinople died soon after Constantine, and it appears as if both church and empire were doomed. Two successors were proposed: Paul, who was supported by a pro-Nicene contingent, and Macedonius, who was supported by the so-called Arians in Constantinople. But both were rejected by the new

39. For a detailed examination of Arius's death in Socrates's Ecclesiastical History, see Muehlberger, "Legend of Arius' Death," 15-18. 
emperor of the East, Constantius II. As we already know, Eusebius of Nicomedia was appointed the archbishop of Constantinople instead.

His first act, which should now sound familiar, was to intervene in Antiochene and Alexandrian affairs. Eusebius immediately convened a synod at Antioch, under the pretense of dedicating the church that the father of the Augusti had commenced, which his son Constantius had finished in the tenth year after its foundations were laid. But his real intent was to subvert and abolish the Nicene doctrine.

In a revealing move, Socrates takes us back to the beginning and reminds us of Athanasius's identity as an exile. All may appear lost, but a return has yet to come. At this point, after the death of Constantine, Athanasius triumphantly reentered Alexandria. Eusebius, aghast at this bold move, called for his second exile and sent his replacement, Gregory of Cappadocia, to Alexandria. Here Socrates slightly alters the story for his own purposes, departing from the details provided by Athanasius in the texts we have already explored. ${ }^{\circ}$ Athanasius, hidden in the midst of his congregants, who were singing psalms, escaped the notice of his would-be captors and fled at once to Rome. It was only after he escaped that Gregory set the Great Church of Alexandria on fire-it is as if the fires of the Great Persecution in Nicomedia had begun once again.

It is this second flight and the climatic moment in Alexandria that marked the end of Eusebius's life. Socrates's description is neither graphic nor detailed. Eusebius does not earn the spectacle of death that Arius had previously provided. We simply hear that Eusebius did not live long enough to hear of the bishop of Rome's support for Athanasius and he simply "died a short time after the Synod was held." (Eccl. Hist. 2.12). The story then quickly passes on to a continued battle over the Constantinopolitan episcopacy. Eusebius's momentary control of Constantinople is overshadowed in Socrates's account by the momentous safe return of Constantine's exhumed body to Constantinople..$^{41}$

As we have seen, Eusebius must be remembered as the bishop of a cursed landscape and not the space of pro-Nicene Christian orthodoxy. And even though Eusebius died in Constantinople, his memory is returned to Nicomedia, just as Constantine's body is transferred back to that holy city. The damning of Nicomedia reinforces how space and place dictate Nicene orthodoxy and immortalized itself in Constantinople.

To briefly summarize, both Athanasius and Eusebius experienced exile and then went on to have successful careers. Eusebius of Nicomedia, like Athanasius,

40. See the previous examination of Athanasius's Defense before Constantius and Defense of His Flight in chapter 2 and his Encyclical Letter in chapter 4.

41. Barnes argues that Constantinople was not simply built on top of Byzantium, but that Byzantium was completely leveled by Constantine; see Barnes, Constantine and Eusebius, 113. Although a relatively insignificant port town, Byzantium was protected by Diocletian during the Gothic raids and then fortified against Maximinus in 311. 
spent a brief time in retreat, followed by a triumphant return. After his exile, he went on to live out an influential and successful career marked by two crowning achievements: he baptized Constantine on his deathbed (although Socrates distances Eusebius from this honor) and was then awarded the coveted bishopric of Constantinople (Socrates, Eccl. Hist. 2.7; Sozomen, Eccl. Hist. 3.4). What we find here is, for all intents and purposes, the makings of an orthodox exile. Yet Eusebius's exile would not be remembered as a testament to his piety. If elaborated on at all, it was used as proof of his guilt, with the noted exception of Philostorgius.

As we have examined here, these two successful bishops fled and returned to different spaces, which would play a significant role in how they would be remembered. Eusebius returned to the space from which he was first exiled, Nicomedia. According to Socrates, Athanasius was initially exiled from Constantinople. And like Constantine, his memory would later be revived and moved to Constantinople, just as Constantine's body was after his death.

Other ecclesiastical historians of the fifth century would go on to damn the Nicomedian landscape and everyone associated with it, as it transformed from a location of imperial persecution, as described by Lactantius and Eusebius of Caesarea, to one infected with heresy, as Socrates envisioned it. In the memorymaking process of the champions of Nicene orthodoxy, Nicomedia's failure was Constantinople's success. Eusebius, that failed bishop, was safely (re)placed where he rightfully belonged. The ecclesiastical historians altered the way in which exile was read, as well as how the spaces and places from which bishops were exiled ought to be remembered. As we have argued here, they did so in order to shape how we tell the heroes from the villains, particularly in those moments when it is not entirely clear who is who. Some spaces were just too powerful to erase. In order to damn the man, we learn, you must also damn the city. At the moment when Eusebius's story concludes and the city of Nicomedia is condemned, another battle of episcopal thrones take place, not in Constantinople, but in the strategically significant location of Antioch.

\section{HOW TO REHABILITATE A CONDEMNED \\ CITY: THEODORET OF CYRRHUS'S ECCLESIASTICAL HISTORY}

All the pro-Nicene historians we have examined throughout this book so far remark that Eustathius, a noted supporter of Athanasius, was targeted by Eusebius of Nicomedia after the Council of Nicaea. Along with his active role in Athanasius's deposition at the Council of Tyre in 335 and the reinstatement of Arius at the Synod of Jerusalem in 335, Eusebius played an important role in the Antiochene politics that would later shape Meletius of Antioch's political life, which will occupy us in the next chapter. Pro-Nicene followers of Eustathius, however, were critical of Athanasius and were subsequently labeled "Arians." Christine 
Shepardson helpfully summarizes the series of events: "In these decades, Antioch hosted a series of councils that attacked Athanasius's theology and authority and the orthodoxy of the Nicene council. Eastern bishops, following Eusebius of Nicomedia, met in Antioch in the winters of 337-338 and 338-339 in efforts to enforce Athanasius's deposition, which the Council of Tyre had advocated in 335 ." $^{42}$ These councils ostensibly allowed for a more ambiguous definition of the Nicene Creed, which enabled Eudoxius, a strongly so-called heteroousian-leaning bishop, to gain hold of the Antiochene see, although he, too, was temporarily exiled in 358 . As a rival, Eudoxius was also named bishop of Constantinople from 360 to 370. Although Eustathius supported Athanasius, the majority of the leaders in Antioch were staunch opponents. ${ }^{43}$ Would this city, alongside Nicomedia, be condemned as well? If John Chrysostom's life and career tell us anything, the answer must be a resounding no. Antioch, and the spaces and places of Nicene orthodoxy, also played a role in further damning Nicomedia and its bishop in an effort to preserve and promote Constantinople.

Theodoret of Cyrrhus, a man who also would find himself in flight, composed his history of the church between 425 and 428, while he was still actively invested in the Antiochene community where he was born and raised (b. 393). Although he was the (reluctant) bishop of Cyrrhus, many have noted his frequent visits to his hometown of Antioch. ${ }^{44}$ Many of Theodoret's modern biographers state that he was heavily influenced by John Chrysostom and the Antiochene bishop Flavian. ${ }^{45}$ Theodoret's episcopal career, like that of many of the bishops we have studied, was also immersed in and defined by controversy. Theodoret was exiled from 449 to 451 due to his involvement in the Christological controversies that occupied the remainder of the fifth century. Most recent scholarship has, therefore, focused on his involvement in the Nestorian controversy, which once again pitted Antioch against Alexandria and was the source of his many troubles. Instead of moving too far along into his episcopal career and the theological debates that occupied him there, we will focus on his preservation of a pro-Nicene legacy in his earlier work. Specifically, we will examine his exilic discourse on Eusebius of Nicomedia to reinforce the spatial arguments we have explored so far. Theodoret's spatial politics, much like those of Socrates, are key to his memory-making enterprise.

42. Shepardson, Controlling Contested Places, 489. Cf. Ayres, Nicaea and Its Legacy, 174-76, 226-28.

43. This may be one of the chief reasons why Gregory of Nazianzus attempted to reintroduce Athanasian orthodoxy through his panegyric. See chapter 1.

44. For a recent investigation of Theodoret and his social network, see Adam Schor, Theodoret's People: Social Networks and Religious Conflict in late Roman Syria (Berkeley: University of California Press, 2011), 19-39. For a thorough investigation of Theodoret's life, see Theresa Urbainczyk, Theodoret of Cyrrhus: The Bishop and the Holy Man (Ann Arbor: University of Michigan Press, 2002), 11-28.

45. As in the case of Socrates, knowledge of Theodoret's life stems mostly from his own works; see P. Canivet, Le monachisme Syrian salon Théodoret de Cyr., ThH 42 (Paris: Beauchesne, 1977), 37-63. 
Theodoret does not start with the council of Nicaea, like the other pro-Nicene historians we have examined. Instead, he zeroes in on the city of Alexandria and the birth of the Arian controversy. After describing a number of heresies that plagued this city, he then presents a list of trustworthy bishops along with a series of letters exchanged between each of these men to verify their legitimacy. It is quite striking that Alexander of Alexandria and Alexander of Constantinople are twin pillars of orthodoxy at the start of this narrative. According to Theodoret, pro-Nicene orthodoxy was already firmly rooted in both locations even before the council took place. Their example and alliance paved the way for their staunchest supporter and chief protagonist, Athanasius, who would stop at nothing to see their vision of orthodoxy fully realized across the rest of the empire.

The fiercest battle, however, took place in that city stuck in the middle, between these twin pillars: Antioch. In this account, we see how Eusebius of Nicomedia becomes the literary foil to Athanasius's every move. Theodoret claims that, like Arius, "he too vomited forth his own impiety" (Eccl. Hist. 1.4). It is not from Nicomedia that Eusebius will do the most damage, but from Antioch.

Before Theodoret turns to Antioch, we learn a great deal more about Eusebius's duplicitous nature and wandering habits. He too reaffirms Eusebius's prior appointment at Berytus and his penchant for spreading discord across the eastern empire. Theodoret also champions Constantine as a savior king. And like Eusebius of Caesarea, Theodoret describes Constantine as a well-intentioned emperor who was, unfortunately, easily deceived by false Christians such as the Eusebians. The emperor, however, would soon see through to Eusebius's true nature once Arius and his followers fled to Nicomedia. Eusebius was condemned and banished to Gaul not just because he protected heretics but also because he openly participated in their evil deeds. As we now know, this exile was only temporary. Theodoret concludes: "But the exiled bishops, employing their customary artifices, abused the benevolence of the emperor, renewed previous contents, and regained their former power" (Eccl. Hist. 1.19). And similar to what we find in other accounts, Eusebius's persuasive powers eventually resulted in his gaining control of Constantinople. It is this move-which was passed over quickly by Socrates-that Theodoret singles out as the true cause behind Eusebius's influence over Antiochene politics.

Much like Sozomen, with whom we will engage in more depth in the next chapter, Theodoret describes Eustathius-the first to experience exile from his episcopal post in Antioch-as the victim of the Eusebian (read: Arian) efforts to infect the empire by way of this strategic city. ${ }^{46}$ On his way to Constantinople, on the emperor's dime, Eusebius and his compatriot and fellow former exile, Theognis, stop temporarily in Antioch. While there, they stir up trouble and frame Eustathius by recruiting a woman of ill repute to accuse him of fathering and then abandoning her child. No other witnesses are brought forth, and Eustathius is condemned and banished to 
Illyricum. Thus began a fierce battle over Antioch's episcopal see. A series of Arians take hold of it but are unable to maintain control for any extensive period. After this woman of ill repute was struck with an illness - a story we have heard before-she confesses to her crime, and Eustathius's reputation was preserved. But the damage had been done, and Eustathius did not return. The outcome was a series of bishops competing for control of Antioch, which bound Alexandria to Antiochene politics and would be the source of significant strife from around 326 through 415 .

This fierce competition in Antioch preoccupies the entirety of book 2 of Theoderet's Ecclesiastical History. Theodoret's discourse on Christian flight was thoroughly shaped by Athanasius's account in his Defense of His Flight. ${ }^{47}$ He includes direct excerpts from the text to amplify his case. Time and time again, the cause of exile is characterized as the handiwork of the enemies of Athanasius and his supporters. There are no tactics they will avoid to dupe an emperor, slander righteous men, or chase saintly men out of their cities, only to murder them later. It was only natural, then, that the defenders of Nicaea flee to escape these power-hungry enemies of the true church. Yet heretics also flee. And their unholy flights, Theodoret insists, are evidence of their guilt (Eccl. Hist. 2.6). What, then, determines whether a bishop's flight is orthodox? According to Theodoret, it is one's dealings with Antioch.

Like Socrates, Theodoret is bound by spatial politics, but his dealings with heretical exiles start and end with his hometown. His heresiological conclusions are further challenged by another fleeing bishop, Meletius of Antioch, whom we will explore in greater depth in the following chapter. For now, it is enough to say that Theodoret, like Socrates, condemned Eusebius of Nicomedia precisely because his exile did not match up to Athanasius's many flights. His further involvement in Antiochene politics only confirmed this point.

\section{CONCLUSION}

Nicaea's legacy was crystalized in the ecclesiastical histories composed during and after the turn of the fifth century. Although Eusebius of Caesarea skirted around many of the theological battles waged between pro- and anti-Nicenes soon after the famed council, the fifth-century writers we encountered in this chapter took a different approach, recounting for their readers all the harried details that occupied the majority of the fourth century. But as we have begun to see, each historian shaped the past to meet the needs and demands of his own historical moment. And in the writings of the fifth-century authors explored here, Nicaea's victory was already assumed, and a Christian empire, however imaginary, was firmly in place. ${ }^{48}$

47. See discussion in chapter 2.

48. Lim also focuses his attention on other ecclesiastical historians are also writing around this period, including Rufinus of Aquileia and Gelasius of Cyzicus; see Lim, Public Disputation, 209-13. In 
These later writers often relied upon the writings of Athanasius as well as other heresiologists to reconstruct their version of the pro-Nicene story. ${ }^{49}$ And in their most revealing moments, these historians deviated from earlier narratives (and evidence) to identify and reflect on their contemporary theological and political debates. Socrates, invested in the preservation of a Constantinopolitan vision of orthodoxy, could not allow Eusebius to lay claim to that space. Instead, he must expel the memory of that failed bishop in order to preserve an Athanasian legacy. Theodoret too would preserve an Athanasian memory, but looked to the battle over Antioch to stake his spatial claims. The Christological controversies of Theodoret's day required him to condemn Eusebius and Nicomedia from a more eastern context. As the theological battles shifted further away from Rome, the exiles of the fifth century would continue to shape the literary landscape.

As we saw with John Chrysostom, how and why one flees often determine whether one's exile is remembered as a success or a failure. As a staunch supporter of Arianism, Eusebius of Nicomedia, the triumphant bishop of the East, all but disappears within pro-Nicene Christian memory, only to resurface as an example of nefarious activity against the orthodox church or of how not to flee. When we do hear of Eusebius's exile, it is characterized as a temporary exile and contrasted with the many sufferings Athanasius was forced to undergo. Eusebius was able to return only through deception, and his failure as an exile only proved this duplicity. Eusebius was recalled from exile after he agreed to sign an agreeable confession of faith, although, as the pro-Nicene biographers insisted, only under false pretenses.

Yet Eusebius's subsequent political and ecclesiastical career was a resounding success: he remained a notable confidant of both Constantine and his son Constantius II, he was awarded the bishopric of Constantinople in 339, he presided over the Antiochene synod in 341, and he died of natural causes. His return from exile should be read as triumphant, and it was by at least one-albeit anti-Niceneecclesiastical historian. He not only baptized the emperor but also was rewarded with the episcopal see at Constantinople. But his legacy was not often tied to Constantinople. His memory, like the city of Nicomedia, slowly fades into infamy, the rubble of which contains the most noxious of men never to be resurrected. His identity as a bishop thus remains a contemptuous one in pro-Nicene Christian memory. His ongoing rejection of Athanasian theology confirmed his legacy as a known heretic and staunch persecutor of the true church.

this chapter and the next, I look primarily at Socrates, Sozomen, and Theodoret for two reasons. First, these authors are heavily invested in the construction of an Eastern Roman Empire with Constantinople at the heart of orthodox urban space. Second, Socrates and Sozomen differ in how they preserve John Chrysostom's legacy. Their treatment of Meletius of Antioch, therefore, reveals a great deal about how a pro-Nicene legacy either accepts or rejects Meletius.

49. See chapters 3 and 5 . 
The contentious history of the episcopal succession in and around Constantinople and its links to the conflict in Antioch will continue to occupy us in our final chapter. Like Eusebius of Nicomedia, Meletius of Antioch will continue to call into question whether an exile was or was not deemed orthodox. The next legacy of Christian flight was a much more difficult case to reconstruct as orthodox. Meletius was a man with a sordid past. Would his baptism of John Chrysostom be enough to clear his name? As we have learned with Eusebius, baptism seems to muddy the waters rather than wash away the stains of a questionable past or future. 